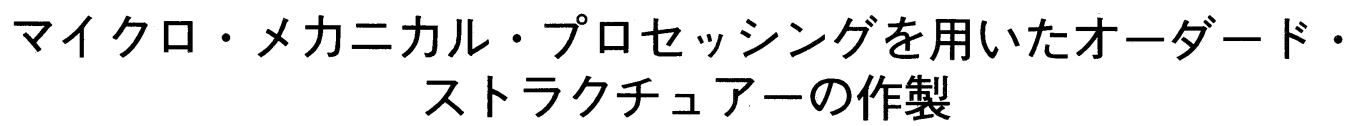

加藤善二・植松敬三

長岡技術科学大学材料開発工学科, 940-21 新潟県長岡市上富岡 1603-1

\title{
Micro Mechanical Processing for Ordered Structure
}

Zenji KATO and Keizo UEMATSU

Department of Material Science and Technology, Nagaoka University of Technology, 1603-1, Kamitomioka, Nagaoka-shi

$940-21$

[Received June 25, 1991; Accepted August 22, 1991]

\begin{abstract}
A novel method for controlling the microstructure of a ceramic green body has been proposed. In this method, spherical granules with uniform size were placed mechanically in a regular array on a mesh, and then moved to a substrate (Micro mechanical processing). To demonstrate the potential of this method, alumina granules with size range $77-85 \mu \mathrm{m}$ were used as a model, and a hexagonal close packed structure was made. Uni-axial pressing of this array can create a uniform and orderly structured green body (Ordered structure).
\end{abstract}

Key-words : Regular array, Granule, Microstructure, Green body, Optical microscope, Mesh

\section{1. 緒 言}

欠陥はセラミックスの様々な特性を支配する. 高性能セ ラミックスの作製に打ける基本的条件は欠陷の少ない成形 体を得ることである．著者らはセラミックプロセッシン グ，特にプレス成形に注目し，顆粒や成形体中の欠陥の評 価1) や顆粒の密度を正確に実測するための方法の開発 ${ }^{2)}$ 行ってきた. 本研究ではいままでに得られた知見を基礎と して, 成形体の構造を制御する新しい方法を提案する.

本報で提案するプロセッシングでは，顆粒を機械的手法 を用いて並べることにより数十ミクロンのオーダーで規則 的な配列をもつ構造を得る.このプロセッシングを，微視 的機械的に構造を制御するという意味から“マイクロ・メ カニカル・プロセッシング”と呼ぶこととする.この方法 は従来単分散粒子を物理化学的に規則配列させる方法 ${ }^{3)}$ 対応するものであるが，原理的に大型の成形体の作製が可 能である．また成形体中に含まれる欠陥も小型となる．例 えば，粒径を揃えた数十 $\mu \mathrm{m}$ の顆粒を単位粒子として規則 的に並べて作製した成形体（オーダード・ストラクチュア 一）は，原理的に数 $\mu \mathrm{m}$ の大きさの欠陥構造しかとりえな い.

本方法はまた数十 $\mu \mathrm{m}$ 単位で規則的に複合化した材料の 作製も可能とする.なお，本提案による成形体の作製にお いて障害となることは，粒子を規則的に並べる際の配列の 精度とそれに要する時間である. その解決には高い精度と 効率をもつ配列方法の開発が必要である. 本研究ではその
開発の第一段階として，最密充填した 2 次元配列粒子の 作製法について報告する.

すなわち，適切なパターンをもつメッシュを用い，顆粒 をのせて最密充填配列をとらせる，ついでこれを固定し， 更に一軸成形を行うことにより成形体とする.

\section{2. 実 験}

配列試料にはスプレードライヤーで乾燥造粒したアルミ ナ顆粒を $77 \mu \mathrm{m}$ と $85 \mu \mathrm{m}$ のふるいで分級した物を用いた. 顆粒を規則的に配列させるには微細な穴を有する金属メッ シュを用いた。メッシュは銅製で穴の形は六角形で，穴の パターンは六方最密充填で, 各穴の内接径は $46 \mu \mathrm{m}$, 隣り 合う穴の中心間の距離は83 $\mu \mathrm{m}$ であった.

図 1 に顆粒を配列させるための方法を示す．六配位の穴 をもつメッシュ上に顆粒を一つずつおくと, 最密充填に近 い顆粒の配列が得られる. 図 2 に顆粒の配列に用いた装置 を模式的に示す．装置は上部に実体顕微鏡（ニコン, $\mathrm{SMZ}-2 \mathrm{~B})$ を，下部に金属顕微鏡試料台を組み合わせて 自作した．試料の配列のためのメッシュはガラス管の上に 固定し，このガラス管を減圧してメッシュの穴から空気を 吸い込ませる．実体顕微鏡で観察しながら，ふるい分けた 顆粒をメッシュの穴の中に注意深く置く.この際，メッシュ 上の各穴には一個の顆粒のみが固定されていることを確認 後, 減圧を止める.メッシュ上に配列された顆粒を, 半透 明の接着剤を約 $40 \mu \mathrm{m}$ の厚さに均一に塗ったスライドガ
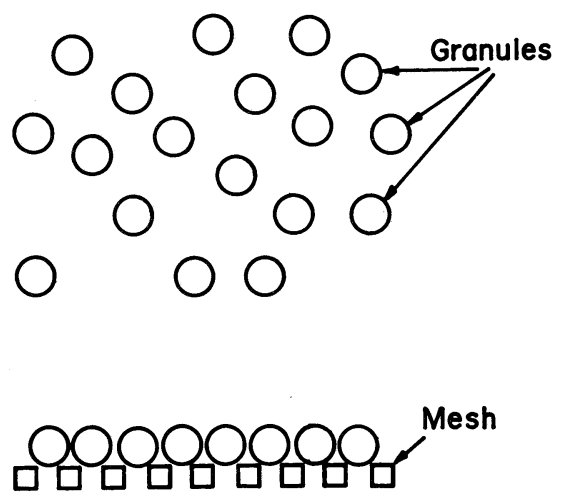

Fig. 1. Principle of granule array by a mesh. 


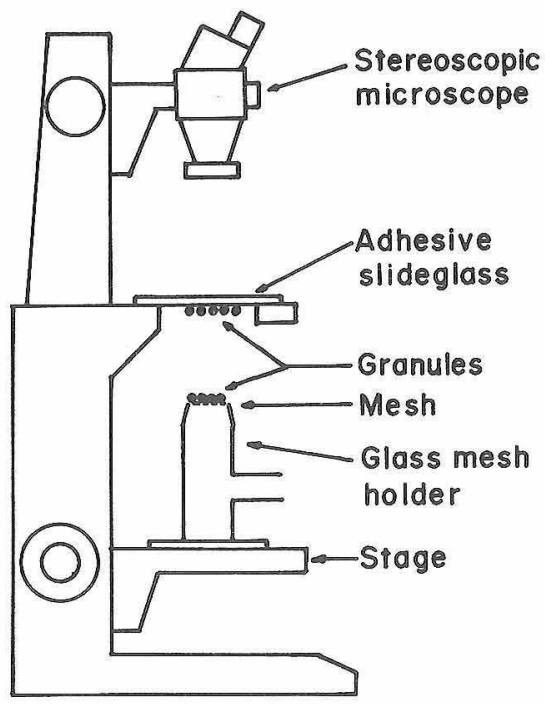

Fig. 2. Schematic diagram of apparatus to array granules.

ラス板に，顆粒との接着面を観察しながら下方からゆっく り動かして固定する。固定された配列顆粒は，内部を鏡面 仕上げを行った超硬ダイス（内径 $1 \mathrm{~cm}$ ) を用いて一軸成 形した。組織は走査型電子顕微鏡 (SEM ; 日本電子, STM-T100) で評価した。

\section{3. 結 果}

図 3 に配列させた最密充填層の SEM 写真を示す。球状 の顆粒が最密充填に近い形で正六面体状に極めて規則的に 配列している．写真では見掛け上配列の中心部では，带電 防止のための金及び炭素の蒸着が不十分なためか顆粒の輪 郭が不明膫であったが，実体光学顕微鏡による観察では， 顆粒の充填状態は外側のそれと同じように極めて緻密でほ とんど接触している。また写真では十分にふるい分けられ なかった非球形の顆粒を若干個含んでいるが，その防止は 将来的には装置の改善で対応可能である.

図 4 に一軸成形した顆粒のSEM 写真を示す。顆粒は全 体的に均一につぶれ, 顆粒の最密充媜構造に対応して正六 面体構造に近づく．屯た個々の顆粒は均一には変形せず， 周りの一部が裂けるようにして変形していることが分か る. 更に中心がへこんだそれは，中空の顆粒が変形したも のと思われる。

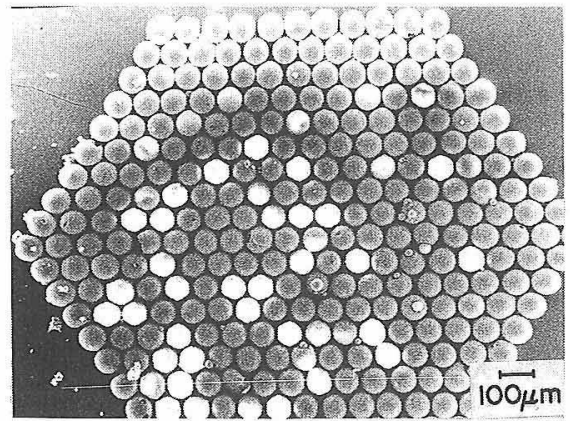

Fig. 3. SEM micrograph of regulary arrayed granules.
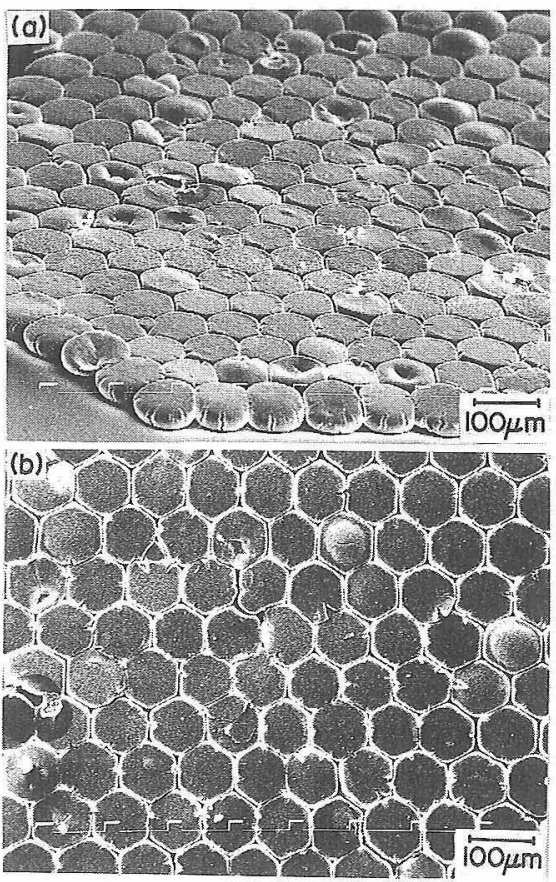

Fig. 4. (a), (b) SEM micrograph of uni-axially pressed structure of regulary arrayed granules.

\section{4. 考 察}

高性能セラミックスのための規則的な構造を作製するプ

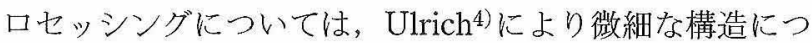
いての化学的観点からの取り扱いが報告されている. 本研 究の上うに比較的大きな構造についてははじめてである。

本研究の方法では図 4 に示したと扝り，顆粒間の隙間 は十分に埋められている。従来の加圧成形プロセスでは， 加厈前の顆粒のパッキング状態が局所的に変動している場 合，成形後に密度变化が生じ，局所的に大きな気孔が残る と考えられる。本方法では顆粒間の界面に生じると考えら れる久陥は小さくかつ規則的に並ぶ.このように本方法で は均一な成形体を得ることができる。

強度材料では欠陥の少ないことが必要であるが，本研究 の方法をもってしても従来のセラミックプロセッシング （スリップキャスト，射出成形，粉体圧縮など）と同様， 完全に欠陥のない材料を作ることは非常に困難である。し かしながら，本研究の方法ではたとえ欠陷が存在しても， それが制御された形で存在するため材料の信頼性は向上す ると考えられる。

本方法は以下に示すとおり多くの優れた特徵をもち新し いセラミックスの作製概念の一つのモデルとなる.

(1）メッシュのパターンを変えれば，異なった充填構 造が作製できる。

（2）異なったパターンのメッシュの組み合わせで，材 料の精密な複合化が行える.

（3）多層化により規則構造をもつバルク材料も作製で きる．例えば，直径 $100 \mu \mathrm{m}$ の顆粒を用いる時，100回程 度重ねることで $1 \mathrm{~cm}$ の厚さの成形体が作製できる。

この方法の実用化に際しては，当面次の二つの問題点を 
克服しなくてはならない. まず従来のセラミックプロセッ シング以上の高精度の制御技術を必要とすることである.

メッシュー顆粒の位置合わせやメッシュパターンの作製に 対しては最近の半導体作製の技術が利用できる. 配列用の メッシュはエッチング技術により容易に作製することがで きる. 適切な機械によりメッシュを $1 \mu \mathrm{m}$ の精度で動かす ことは容易である.

次に粒径の揃った均一で緻密な顆粒の作製がある。しか し，またこの点も最近の進歩した粉体作製技術，例えば， マイクロカプセル作製の技術5)などを用いれば，容易に克
服されると考えられる.

\section{文 献}

1）植松敬三, 粉体工学会誌, 28, 251-56 (1991) ; 植松敬三, FC Report, 9, 187-93 (1991).

2) Z. Kato, J. Y. Kim, K. Saito and K. Uematsu, Am. Ceram. Soc. Bull., 70, 129-31 (1991).

3) E. A. Barringer and H. K. Bowen, Comm. Am. Ceram. Soc., 65, C199-201 (1982).

4) D. R. Ulrich, "Ultrastructure Processing of Ceramic, Glass and Composites", Ed. by L. L. Hench and D. R. Ulrich, Wiley-Interscience, New York (1984) pp. 6-11.

5）小石真純編, “微粒子設計”, 工業調查会 (1987) pp. 73-125. 